\title{
POLITYKA LOKALNA GMINY UNIEJÓW - WYBRANE ASPEKTY TEORETYCZNE I PRAKTYCZNE
}

Zarys treści W artykule omówiono sposób (metodę) prowadzenia przez władze samorządowe polityki lokalnej w małym mieście na przykładzie Uniejowa. Charakterystyki tego zagadnienia dokonano w oparciu o zaprezentowany przez J. Regulskiego schemat kreowania w mieście polityki lokalnej. Tym samym autorki skoncentrowały się przede wszystkim na identyfikacji wizji i celów prowadzonej w Uniejowie polityki lokalnej, przedstawieniu przyjętej przez władze lokalne strategii, w tym etapów jej powstawania i zastosowanych narzędzi oraz analizie podjętych działań, które w założeniu służą realizacji przyjętej wizji rozwoju. Ponadto, w artykule podjęto badania społeczne, których celem była identyfikacja i ocena stopnia zadowolenia mieszkańców miasta oraz odwiedzających go turystów z prowadzonej przez władze polityki lokalnej.

Słowa kluczowe Polityka lokalna, władze samorządowe, rozwój lokalny, Uniejów.

\section{Wprowadzenie}

Głównym celem artykułu jest identyfikacja sposobu (metody) prowadzenia przez władze samorządowe Uniejowa polityki lokalnej oraz jej społeczna percepcja. W szczególności podjęte badania koncentrują się na:

- przedstawieniu przyjętej przez władze samorządowe wizji rozwoju miasta,

- identyfikacji i charakterystyce stosowanych przez władze miasta instrumentów oddziaływania,

- ocenie przez mieszkańców i przyjezdnych prowadzonej przez władze polityki lokalnej.

Miastem, w którym prowadzono badania był Uniejów i nie był to wybór przypadkowy. Jeszcze bowiem do niedawna Uniejów było to niewielkie, rolnicze miasteczko, które na mapie Polski nie wyróżniało się niczym szczególnym. Większą uwage przyciągał jedynie dobrze zachowany, pochodzący z XIV wieku zamek 
arcybiskupów gnieźnieńskich oraz ulokowany w jego sąsiedztwie park, który w połączeniu z rzeką Wartą tworzy urokliwy i wyjątkowy krajobraz.

Przez cały okres gospodarki centralnie planowanej oraz w ciągu pierwszych 10 lat transformacji systemowej było to jedno $z$ najmniejszych i zarazem najbiedniejszych miast regionu łódzkiego. Wraz z dwoma innymi miastami znajdowało się najniżej $\mathrm{w}$ hierarchii miejskiego systemu osadniczego regionu łódzkiego (Suliborski, Walkiewicz 2009). Jego struktura gospodarcza miała charakter rolniczo-usługowy nastawiony głównie na obsługę lokalnych mieszkańców, a funkcją dominującą był handel. Negatywnie na rozwój miasta wpłynęły zmiany spowodowane transformacją systemową. Wraz z nadejściem gospodarki rynkowej w ruinę popadły bowiem działające $\mathrm{w}$ okresie PRL-u zakłady przemysłowe, a to z kolei przyczyniło się do powstania w mieście niekorzystnych zjawisk demograficznych, tj. bezrobocia, depopulacji itp. (Kulawiak 2013).

Współcześnie miasto to przeżywa jednak ,drugą młodość”, gdyż od blisko 10 lat należy do najbardziej dynamicznie rozwijających się miast w regionie łódzkim, o czym świadczy zarówno poprawa sytuacji na lokalnym rynku pracy (rys. 1), znaczny wzrost lokalnej przedsiębiorczości wyrażony liczbą podmiotów gospodarczych (rys. 2) oraz wzrost dochodów gminy (rys. 3), jak też fakt, że w 2012 roku z małego, rolniczego miasteczka Uniejów przeistoczył się w pierwsze w Polsce uzdrowisko termalne.

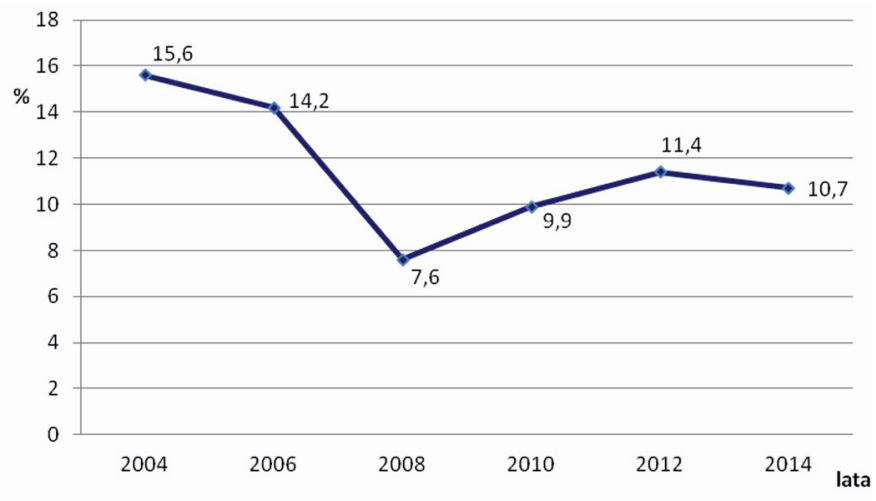

Rys. 1. Udział osób zarejestrowanych jako bezrobotni w ogólnej liczbie aktywnych zawodowo w gminie Uniejów w latach 2004-2014

Źródło: opracowanie własne na podstawie danych z BDL (luty 2014)

Obecny sukces Uniejowa jest splotem wielu różnorodnych czynników, jednak znaczenie priorytetowe należy przypisać działaniu jego władz, a co za tym idzie również przemyślanej i konsekwentnie realizowanej polityce lokalnej. Polityka ta oparta jest na wszechstronnym wykorzystaniu potencjału turystycznego, społecznego, gospodarczego oraz przyrodniczego (wody geotermalne) oraz bazuje 
na innowacyjnym, strategicznym i długofalowym planowaniu rozwoju gminy w kierunku uzdrowiskowym, rekreacyjnym i turystycznym oraz na umiejętnym i skutecznym pozyskiwaniu zewnętrznych środków finansowych - głównie unijnych. Z tego względu, autorki postanowiły bliżej przyjrzeć się prowadzonej przez władze gminy Uniejów polityce lokalnej.

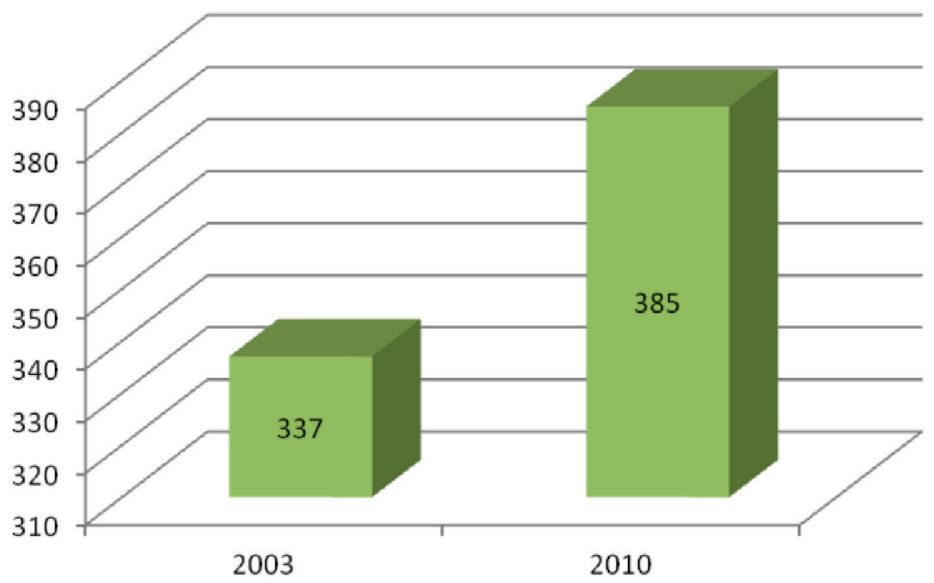

Rys. 2. Liczba podmiotów gospodarki narodowej w gminie Uniejów w latach 2003 i 2010 Źródło: opracowanie własne na podstawie danych z BDL (luty 2014)

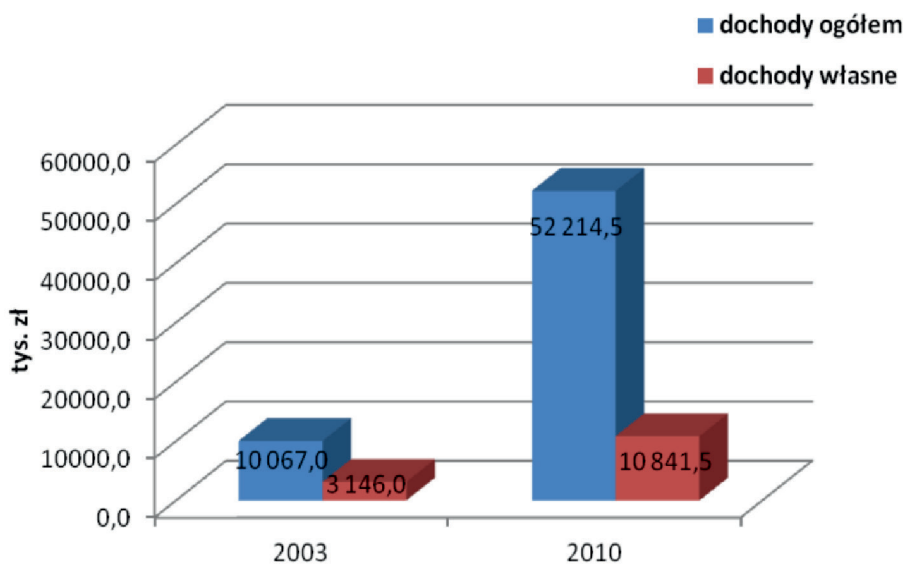

Rys. 3. Dochody budżetu gminy Uniejów w podziale na dochody własne i ogółem w latach 2003 i 2010

Źródło: opracowanie własne na podstawie danych z BDL (luty 2014) 
Biorąc pod uwagę przyjętą problematykę uznano, że postępowanie badawcze ma mieć przede wszystkim charakter jakościowy i podejście to znalazło swoje odzwierciedlenie w doborze metod, sposobie interpretacji wyników oraz celowym, a nie losowym doborze respondentów. W związku z tym, w artykule zastosowano przede wszystkim własne badania empiryczne, w tym wywiad kwestionariuszowy przeprowadzony w formie pisemnej i ustnej oraz badania obserwacyjne. Wywiad kwestionariuszowy przeprowadzono na grupie 100 osób w latach 2010-2013, a jego głównym celem było uzyskanie informacji na temat postrzegania przez mieszkańców i odwiedzających miasto działań podejmowanych przez władze samorządowe gminy Uniejów. $Z$ tego względu grupę respondentów tworzyli przede wszystkim mieszkańcy Uniejowa oraz turyści, którzy w tym okresie odwiedzili miasto. Ponadto, w badaniach zastosowano również wspomniane metody obserwacyjne, w tym obserwację bezpośrednią i uczestniczącą. Dzięki tej metodzie możliwe było lepsze zrozumienie wyników wywiadów kwestionariuszowych. Poza wymienionymi, ważnym źródłem informacji były także liczne opracowania i dokumenty urzędowe pozyskane w wyniku kwerendy w Urzędzie Miasta Uniejów, takie jak: Strategia Rozwoju Gminy Uniejów na lata 2013-2020, Plan Rozwoju Lokalnego Gminy na lata 2007-2015, a także Lokalny Program Rewitalizacji na lata 2011-2018 oraz dane kartograficzne i statystyczne dotyczące bieżącej sytuacji społeczno-gospodarczej Uniejowa.

\section{Pojęcie polityki i polityki lokalnej oraz fazy jej tworzenia}

Termin polityka pochodzi z języka greckiego i na przestrzeni lat ulegał ewolucji. Początkowo politykę rozumiano jako sztukę rządzenia państwem dla osiągnięcia dobra wspólnego (Arystoteles). W latach 70. ubiegłego wieku politykę określano jako działalność władzy państwowej, rządu w dziedzinach społecznej, gospodarczej, kulturalnej, wojskowej i innych dotyczącą spraw wewnętrznych państwa lub stosunków z innymi krajami, jak również wzajemnych stosunków klas, grup społecznych uwarunkowana określonymi celami i interesami, mająca również na celu zdobycie i utrzymanie władzy państwowej. W latach 80 . z kolei polityka definiowana była jako świadome, ciągłe i suwerenne oddziaływanie na procesy z natury swej nie dające sie w pełni sterować.

Współcześnie pojęcie to definiowane jest na wiele różnych sposobów. Przyjmując założenie, że ,źródłem polityki jest sprzeczność i rozbieżność interesów oraz aspiracji grupowych wynikająca ze zróżnicowania społeczeństwa", m.in. J. Parysek zdefiniował politykę jako działania ludzi o odmiennych interesach dla osiągnięcia wspólnych celów lub konkurencja w realizacji celów indywidualnych (Parysek 2001). 
Inne ujęcie polityki wskazuje z kolei na relacje miedzy ośrodkiem władzy a pozostałymi uczestnikami życia społecznego i gospodarczego definiując ją jako działalność wytyczoną przez kierowniczy ośrodek organizacji społecznej, aby zrealizować cele ważne dla jednej lub wielu dziedzin życia społecznego, przy czym między ośrodkiem kierowniczym a członkami organizacji istnieje stosunek władzy (Markowski 1999). Niezależnie od preferowanego podejścia, w literaturze przedmiotu istnieje jednak zgodność co do tego, że charakterystyczną cechą polityki jest i powinno być oddziaływanie na wiele różnych jednostek posiadających pewien zakres autonomii (ludność, przedsiębiorstwa), a działanie to powinno wywołać pożądane zachowanie, zgodne z zamierzonymi celami. Tym samym polityka jest przede wszystkim działaniem celowym, którą prowadzi podmiot posiadający pewien zakres autonomii oraz związane z nim instytucje.

Przedmiotem niniejszego artykułu jest polityka lokalna. Pierwotnie oznaczała ona sztukę rządzenia miastem dla osiągnięcia dobra wspólnego (w interesie ogólnospołecznym) (Arystoteles). Współcześnie, w literaturze przedmiotu, polityka lokalna definiowana jest natomiast jako planowa i zorganizowana działalność organów samorządu terytorialnego i innych jednostek publicznych podporządkowanych tym organom, które bezpośrednio dysponują środkami władzy (takimi jak: koordynacji, przymusu, kontroli, represji) polegająca na wyborze celów służących interesom społeczności lokalnej oraz wyborze środków do osiągnięcia tych celów (Masik 2010). W praktyce życia społeczno-gospodarczego istota polityki lokalnej polega na określeniu sposobów, standardów i zakresu wykonywania zadań publicznych oraz alokacji środków finansowych i zasobów technicznych, które stanowią własność komunalną. Tak rozumiana polityka lokalna jest zatem działalnością władz lokalnych w dziedzinie społecznej, gospodarczej i kulturalnej w warunkach nieustającej gry o zasoby i sposoby ich redystrybucji.

Działania podejmowane przez władze lokalne na rzecz kreowania polityki lokalnej obejmują zdaniem J. Regulskiego trzy podstawowe fazy:

I Określenie celów, czyli sformułowanie odpowiedzi na pytanie, po co działamy, czy też „co chcemy osiągnąć” (faza ta zawiera wybory o charakterze politycznym);

II Opracowanie i przyjęcie strategii, czyli określenie sekwencji działań i zadań dla poszczególnych wykonawców (co, gdzie, kiedy mamy zrobić, aby osiągnąć cel) - jest to faza prac planistycznych;

III Sterowanie rozwojem, czyli podejmowanie działań powodujących realne zmiany w strukturze lub funkcjonowaniu danego systemu, które mają służyć osiąganiu celów (Regulski, Kocon, Ptaszyńska-Wołoczkowicz 1988).

W artykule podjęto próbę identyfikacji sposobu prowadzenia polityki lokalnej przez władze samorządowe wykorzystując powyższy schemat postępowania. 


\section{Tworzenie polityki lokalnej przez władze gminy Uniejów - faza I (określenie celów działań i wizji przez władzę)}

Zgodnie z przyjętą przez J. Regulskiego koncepcją faz tworzenia polityki lokalnej, faza pierwsza obejmuje określenie przez władzę konkretnych celów i wizji rozwoju gminy. Wychodząc z przekonania i założenia, że władza jest podmiotem kluczowym, od którego zależy tworzenie polityki, postanowiono przeanalizować i zidentyfikować główne cechy władzy samorządowej gminy Uniejów determinujące ich działania i decydujące o osiąganiu sukcesów.

$\mathrm{W}$ odniesieniu do Uniejowa jego rozwój związany jest z podjęciem przez przedstawicieli władzy decyzji i następnie kroków w kierunku przekształcania miasta z lokalnego ośrodka o niewykorzystanym potencjale turystycznym w miejscowość o dużym znaczeniu w skali ponadregionalnej szczególnie dla turystyki uzdrowiskowej i rekreacji.

Osoby zarządzające gminą Uniejów od początku, gdy tylko pojawiła się realna możliwość eksploatowania wód geotermalnych, zauważały liczne korzyści ze zrównoważonego rozwoju miejscowości i regionu opartego na wykorzystaniu tego surowca. Decydenci uznali, że geotermia jest dużą szansą na rozwój gospodarczy Uniejowa, głównie w kierunku turystyki uzdrowiskowej i rekreacji. Według nich wykorzystanie wody geotermalnej otworzyło w historii miasta nowy rozdział związany z inwestycjami geotermalnymi, usługami turystycznymi i przemianami funkcjonalnymi i fizjonomicznymi przestrzeni miejskiej oraz całej gminy. Niewątpliwie do rozwoju geotermii i turystyki w Uniejowie przyczyniły się pozytywne przykłady miejscowości zagranicznych o podobnym profilu, m.in. na Węgrzech, Słowacji i w Austrii (Smętkiewicz 2014).

Dynamiczne pozytywne przemiany w sytuacji społeczno-gospodarczej gminy Uniejów zbiegają się z objęciem funkcji burmistrza przez Józefa Kaczmarka w 2002 roku. Począwszy od pierwszych wygranych wyborów do ostatnich

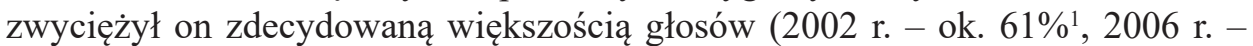
ok. $93 \%^{2}, 2010$ r. - ok. $87 \%^{3}, 2014$ r. - ok. $88 \%{ }^{4}$ ), przy czym warto podkreślić, że już po pierwszej kadencji był on jedynym kandydatem na stanowisko burmistrza. Fakt, że burmistrz J. Kaczmarek pełni władzę nieprzerwanie od 13 lat, również świadczy o dużym zaufaniu społecznym, którym mieszkańcy darzą jego osobę i politykę lokalną realizowaną przez cały samorząd.

Przedstawiciele władzy samorządowej charakteryzują się następującymi cechami determinującymi ich działania i decydującymi o osiąganiu sukcesów:

\footnotetext{
${ }^{1}$ http://wybory2002.pkw.gov.pl/wojt/t1/gw1/w10/p1011/g101104.html(dostęp: 13.04.2015).

${ }^{2} \mathrm{http}: / /$ wybory2006.pkw.gov.pl/kbw/geoGminafea5.html?id=101104\& (dostęp: 13.04.2015).

${ }^{3} \mathrm{http}: / /$ wybory2010.pkw.gov.pl/geo/pl/100000/101104.html\#tabs-6 (dostęp: 13.04.2015).

4 „Uniejowskie Strony”, 2014, 4/44, s. 11.
} 
- odwaga i gotowość do podejmowania ryzyka,

- kreatywność i pomysłowość,

- sprawność i skuteczność w realizacji założonych celów i strategii rozwoju,

- otwartość na doświadczenia innych oraz na zdobywanie wiedzy i doświadczeń,

- wykorzystywanie dobrych przykładów z innych miejscowości, regionów poprzez aktywny udział w wizytach studyjnych, konferencjach, spotkaniach, targach branżowych,

- jednomyślność podmiotów decyzyjnych - prowadzenie działań dla dobra wspólnego interesu,

- umiejętność zjednywania i przekonywania innych osób, podmiotów gospodarczych i instytucji do celowości realizacji określonych pomysłów i wizji,

- priorytetowe traktowanie dobra mieszkańców i dbałość o interesy społeczności lokalnej.

Jasno sprecyzowana i konsekwentnie realizowana polityka lokalna w Uniejowie i wizja rozwoju gminy zdecydowanie determinuje rozwój społeczno-gospodarczy miasta i gminy, jednak spotyka się to z akceptacją ze strony społeczności lokalnej.

Od samego początku burmistrz J. Kaczmarek wraz z całym zespołem sprawującym władzę samorządową w gminie Uniejów realizuje konsekwentnie wizję Uniejowa jako uzdrowiska termalnego. Idea ta była możliwa do wdrożenia w życie dzięki przełomowej decyzji władz o wykorzystaniu kluczowego bogactwa przyrodniczego Uniejowa, tj. wód geotermalnych. Wizja rozwoju gminy Uniejów bazuje ponadto na innych głównych mocnych stronach gminy, jakie stanowią (Gorczyczewska, Smętkiewicz 2013):

- bogate zasoby wód geotermalnych,

- korzystne dla zdrowia właściwości wód geotermalnych i warunków bioklimatycznych, które stały się podstawią do uzyskania w 2012 roku statusu uzdrowiska termalnego (Uniejów został najmłodszym polskim uzdrowiskiem i jedynym w województwie łódzkim),

- korzystne położenie komunikacyjne w centrum Polski, bezpośrednie połączenie z autostradą A2 oraz bliskość dużych aglomeracji miejskich: Łodzi, Poznania, Warszawy,

- rzeka Warta, walory środowiska przyrodniczego, formy ochrony przyrody,

- dobrze rozwinięta infrastruktura techniczna, a szczególnie turystyczna,

- dobrze wypromowane walory i atrakcje historyczno-kulturowe, w tym atrakcyjna oferta wydarzeń tematycznych,

- wykorzystanie OZE: geotermia, biomasa, energetyka wiatrowa i w przyszłości słoneczna,

- doświadczenie i skuteczność w pozyskiwaniu środków zewnętrznych, głównie unijnych. 
Dzięki jasno sprecyzowanej wizji gminy realnym stało się prowadzenie polityki lokalnej determinowanej wizją zrównoważonego rozwoju gminy bazującego na zastosowaniu wód geotermalnych i, jak dotąd niepełnym, wykorzystaniu potencjału przyrodniczego, społecznego i ekonomicznego gminy - a szczególnie jej cennych walorów turystycznych.

W ciągu ostatniej dekady oblicze Uniejowa zaczęło się zdecydowanie zmieniać w kierunku swoistej „kapsuły zdrowia i witalności” - miejscowości uzdrowiskowej oferującej szeroką gamę możliwości aktywnej rekreacji, regeneracji sił i profilaktyki prozdrowotnej, a także spędzenia czasu z całą, wielopokoleniową rodziną (Kaczmarek, Smętkiewicz 2013). Odpowiednia, kompleksowa promocja wszystkich atrakcji turystycznych gminy Uniejów oparta jest na wykorzystaniu funduszy unijnych i wdrożeniu projektów z zakresu budowy i promocji marki o nazwie: „Termy Uniejów” i „Eko-Uniejów”, dzięki czemu marka „Termy Uniejów" jest markowym produktem turystyki uzdrowiskowej.

\section{Tworzenie polityki lokalnej przez władze gminy Uniejów - faza II (opracowanie strategii działań)}

Faza druga tworzenia polityki lokalnej w podziale przyjętym przez J. Regulskiego związana jest z określeniem rodzajów i kolejności działań, a także celów do osiągnięcia przyjętej wizji. Ten etap realizacji polityki lokalnej przybiera formę opracowania odpowiednich dokumentów i kierowania się ich treściami w podejmowaniu decyzji.

Kluczowymi dokumentami dla gminy Uniejów, na podstawie których została dokładnie określona strategia działań i zostały zaplanowane poszczególne ich etapy w zakresie realizacji założonej polityki lokalnej są: Strategia Rozwoju Gminy Uniejów na lata 2000-2010 oraz na lata 2013-2020, Plan Rozwoju Lokalnego Gminy na lata 2007-2015, a także Lokalny Program Rewitalizacji na lata 20112018.

Opracowanie „Strategia rozwoju Gminy Uniejów na lata 2013-2020” jest dokumentem o charakterze kierunkowym i koncepcyjnym, przedstawia długofalowe cele i priorytety rozwoju gminy, na podstawie których wyznaczone zostaną kierunki działań. Realizacja przyjętej strategii rozwoju gminy odbywa się w ramach wyznaczonych przez wizję i misję gminy określających jej tożsamość, przyszłość oraz sposób, kierunki i charakter działan. Wizja prezentuje stan docelowy gminy, do którego dąży ona w perspektywie najbliższych lat. W przypadku gminy Uniejów założono, że do roku 2020 uzyska ona rozpoznawalny status ośrodka turystyki termalno-uzdrowiskowej i rekreacyjnej w Polsce centralnej, który umiejętnie wykorzystuje swoje walory przyrodnicze i historyczno-kulturalne ${ }^{5}$. Scenariusz realizacji tego celu stanowi misja określająca kierunek i sposób działania.

\footnotetext{
${ }^{5}$ Strategia Rozwoju Gminy Uniejów na lata 2013-2020.
} 
Misją gminy Uniejów jest aktywne zaangażowanie władz gminy, interesariuszy i mieszkańców w budowę pozycji lidera turystyki termalno-uzdrowiskowej i rekreacyjnej w Polsce centralnej.

Realizacja zdefiniowanej w strategii rozwoju gminy wizji i misji opiera się na osiąganiu założonych celów strategicznych i operacyjnych, które wskazują pożądane kierunki rozwoju i konkretyzują obszary działań. Celami strategicznymi i przypisanymi do nich celami operacyjnymi rozwoju gminy są ${ }^{6}$ :

1. Rozwój turystyki poprzez pełne wykorzystanie walorów środowiska naturalnego

- stworzenie i promocja zintegrowanej oferty turystycznej Gminy Uniejów bazującej na zasobach wody geotermalnej,

- rozwój infrastruktury uzdrowiskowej,

- wybór i promocja produktu regionalnego,

- rozwój turystyki historycznej,

- wykorzystanie potencjału rzeki Warty.

2. Wzmacnianie potencjału społeczno-gospodarczego wokół zasobów posiadanych przez gminę

- aktywizacja ducha przedsiębiorczości wśród mieszkańców,

- pozyskiwanie nowych inwestorów,

- rozwój energetyki w oparciu o posiadane przez gminę zasoby.

3. Zrównoważony rozwój infrastruktury na potrzeby mieszkańców i przyjezdnych - rozwój infrastruktury drogowej i okołoturystycznej,

- wspieranie czystości i ochrony środowiska,

- zrównoważony rozwój infrastruktury na potrzeby mieszkańców i przyjezdnych,

- uporządkowanie i odnowa starej tkanki miejskiej,

- dostosowanie oferty kulturalnej do potrzeb mieszkańców,

- rozwój infrastruktury teleinformatycznej.

4. Dostosowanie oferty edukacyjnej, kształcenia zawodowego i ustawicznego do potrzeb lokalnego rynku

- dostosowanie oferty edukacyjnej do potrzeb rynku turystycznego,

- dostosowanie oferty edukacyjnej, kształcenia zawodowego i ustawicznego do potrzeb lokalnego rynku,

- stworzenie zróżnicowanej oferty edukacyjnej dla wszystkich grup wiekowych.

Według założeń zawartych w Strategii Rozwoju Gminy Uniejów na lata 2013-2020, dwa pierwsze cele strategiczne powinny stanowić filary tej strategii - jej „koło zamachowe”, gdyż pozwoli to na zwiększenie dochodów gminy i aktywizację jej mieszkańców. Dwa kolejne cele można natomiast uznać za wspierające, a ich realizacja wpłynie na osiągnięcie zrównoważonego rozwoju we

\footnotetext{
${ }^{6}$ Ibidem.
} 
wszystkich sferach społeczno-gospodarczych i środowiskowych w gminie. Wskazano również, że najbardziej priorytetowo powinny być traktowane cele zaznaczone na powyższej liście wytłuszczoną czcionką.

\section{Tworzenie polityki lokalnej przez władze gminy Uniejów - faza III (podejmowanie działań $\mathbf{w}$ celu realizacji wizji)}

Kolejną fazą tworzenia polityki lokalnej jest sterowanie rozwojem gminy, czyli podejmowanie działań, które skutkują konkretnymi zmianami, a w konsekwencji prowadzą do osiągnięcia założonych celów i realizacji wizji.

Faza ta zawsze odbywa się przy wykorzystaniu różnego rodzaju instrumentów oddziaływania. Przez pojęcie to rozumiemy za J. Regulskim określone prawem sposoby, jakie podmiot polityki, czyli władza może użyć do skłonienia innych jednostek do dostosowania swych zachowań do celów tej polityki (Regulski, Kocon, Ptaszyńska-Wołoczkowicz 1988). W praktyce życia społeczno-gospodarczego władze mają do dyspozycji szereg różnych instrumentów oddziaływania. Próby ich definicji i klasyfikacji były także przedmiotem licznych brac badawczych (Regulski 1986; Winiarski 1986; Markowski 1999; Masik 2000; Swianiewicz 2004). Na potrzeby niniejszego opracowania odwołano się jednak do klasyfikacji

B. Needhana, zdaniem którego instrumenty oddziaływania dzielą się na:

1) oddziaływujące na struktury przestrzenne, w których działają jednostki - są to wszelkiego typu inwestycje władz lokalnych kształtujących materialną przestrzeń,

2) zmieniające finansowe okoliczności działania,

3) zmieniające okoliczności prawne i stopień administracyjnego podporządkowania,

4) informacyjne zmieniające stan wiedzy jednostki o swoim otoczeniu. Warto dodać, że odwołanie się właśnie do tej klasyfikacji, wynika z faktu, że w największym stopniu odpowiadają one działaniom, które władze Uniejowa podejmują na swoim terenie (Needhan 1982).

W Uniejowie, spośród szerokiego wachlarza różnych rodzajów działań, które władze lokalne mogą podejmować na swoim terenie, najczęściej realizowanymi działaniami są te w zakresie:

a) inwestycji (działania o charakterze gospodarczym - inwestowanie w infrastrukturę techniczną i społeczną, w tym kreowanie nowych inwestycji w zakresie przede wszystkim funkcji uzdrowiskowej),

b) marketingu terytorialnego (działania o charakterze promocyjnym - promowanie walorów i atrakcji turystycznych gminy i tworzenie jej pozytywnego wizerunku, budowanie i promocja marki),

c) budżetu (pozyskiwanie i efektywne wykorzystywanie zewnętrznych źródeł finansowania, w tym głównie środków unijnych),

d) polityki społecznej (działania prospołeczne na rzecz poprawy jakości życia mieszkańców); 


\section{a) inwestycje}

Wśród nich znaczenie priorytetowe ma inwestowanie w infrastrukturę społeczną i techniczną. Wyrazem tego jest zrealizowanie w mieście w latach 2004-2015 inwestycji i projektów promocyjnych głównie z zakresu funkcji turystyczno-uzdrowiskowej, ale należy podkreślić, że nie są to działania przypadkowe, lecz wynikają z przyjętego przez włodarzy miasta kierunku jego rozwoju.

Jedną z pierwszych i zarazem najważniejszych inwestycji był kompleks termalno-basenowy „Termy Uniejów”, w skład którego oprócz basenów krytych i otwartych wchodzą również niecki solankowe, zespół wellness oraz Spa. Kolejną był Kasztel Rycerski „Na gorących Źródłach”, który poza możliwością noclegu oferuje również lecznicze kąpiele w baliach dębowych, czy możliwość zwiedzania eksponatów muzealnych prezentujących średniowieczne narzędzia tortur. Należy również wspomnieć o kompleksie sportowym im. W. Smolarka, w skład którego wchodzą pełnowymiarowe boiska do gry w piłkę nożną spełniające wymogi UEFA. Jedno z boisk, jako jedyne takie boisko w Polsce, posiada naturalną murawę podgrzewaną wodą geotermalną.

Władze gminy zainwestowały również w zaplecze tzw. obsługujące inwestycje budując również obiekty gastronomiczne, noclegowe i kulturalne. Przykładem jest Zagroda Młynarska, która obok funkcji restauracyjnej spełnia także funkcję muzealną - na jej obszarze zgromadzono bowiem oryginalne, ale i zrekonstruowane obiekty zabytkowe z terenu Polski Środkowej, m.in. chałupę ze Skotnik, kopię zabytkowej stodoły z Biesiekier, czy dwa XIX-wieczne wiatraki z Chorzepina i Zbylczyc. W tym tzw. „interaktywnym skansenie” można przenocować w wiatraku, a także zdobyć wiedzę o tradycjach ludowych i życiu dawnej wsi oraz własnoręcznie upiec chleb.

W odniesieniu do infrastruktury technicznej, od 2002 roku władze gminy rozbudowały i przebudowały na jej terenie system wodociągowy, kanalizacji zbiorowej oraz sieci wody geotermalnej, doposażyły w infrastrukturę techniczną zespó1 zamkowo-parkowy oraz zrewitalizowały historyczny układ komunikacyjny miasta. Ponadto dozbroiły tereny dotychczas niezainwestowane (połzżone na lewym brzegu Warty) oraz poprowadziły nową ulicę przygotowując ten teren dla przyszłych inwestorów.

\section{b) promocja}

Drugim ważnym atrybutem prowadzonej w Uniejowie polityki lokalnej są działania podejmowane na rzecz promocji miasta, a co za tym idzie kształtowania jego wizerunku, czyli działania związane z marketingiem miejskim (terytorialnym). Należy podkreślić, że działania te, podobnie jak podejmowane inwestycje nie mają charakteru przypadkowego i doraźnego, lecz również wynikają z przyjętych w strategii miasta założeń, wizji - stąd wszystkie z nich realizują jeden cel - wykreowania i utrwalenia w świadomości mieszkańców i potencjalnych 
turystów obrazu Uniejowa jako miasta bazującego przede wszystkim na tradycji średniowiecznej i wodach geotermalnych. Warto podkreślić, że zakres realizowanych w tym celu przez gminę działań jest bardzo szeroki. W Uniejowie odbywają się ogólnopolskie coroczne festiwale tematyczne: Turniej Rycerski na zamku w Uniejowie (lipiec) i Jarmark Średniowieczny na Kasztelu Rycerskim (sierpień), Ogólnopolski Festiwal Muzyki i Tańca Ameryki Północnej POW-WOW (kwiecień), Indiańskie Lato im. Sat-Okha (lipiec), Ogólnopolski Bieg „Do Gorących Źródeł - Sanus per Aquam” (październik), Ogólnopolskie Dni Wody (czerwiec), Dni Uniejowa (maj), Jarmark Bożonarodzeniowy (grudzień). Motyw z herbu miasta - trzy białe lilie posłużyły również jako element promocji poprzez organizację festiwalu związanego tematycznie z tymi kwiatami - Festiwal „Królestwo Lilii”, ukwiecanie najważniejszych miejsc miasta liliami oraz wykorzystanie motywu herbowej lilii w wystroju wnętrz na zamku (Gorczyczewska, Smętkiewicz 2013).

Gmina Uniejów jest beneficjentem dwóch kilkuetapowych projektów w zakresie budowy i promocji marki regionalnej o nazwach: „Termy Uniejów” oraz „Eko-Uniejów”, których całkowita wartość wyniosła ok. 11,3 mln. Projekty te realizowane były w latach 2011-2015 i obejmowały różnorodne działania, takie jak m.in.: reklamy i materiały promocyjne w prasie, telewizji, rozgłośniach radiowych i Internecie, realizacja własnych stron internetowych, organizowanie imprez plenerowych (w tym koncertów i festiwali muzycznych), organizowanie wizyt studyjnych, warsztatów i konferencji naukowych, wydawanie materiałów promocyjnych w postaci folderów i broszur turystycznych i popularno-naukowych.

Gmina Uniejów współpracuje z Centralnym Łukiem Turystycznym - razem z tym stowarzyszeniem bierze udział w różnego rodzaju targach i wydarzeniach promocyjnych, m.in. w międzynarodowych targach turystycznych (w Poznaniu, Łodzi, Warszawie, Berlinie), Jarmarku Wojewódzkim (obecnie pod nazwą Mixer Regionalny).

Władze samorządowe gminy Uniejów współpracują także z uczelniami wyższymi: Wojskową Akademią Techniczną w Warszawie, Uniwersytetem Medycznym w Łodzi, Politechniką Łódzką, Akademią Sztuk Pięknych w Łodzi, Instytutem Ogrodnictwa w Skierniewicach oraz z Uniwersytetem Łódzkim. Dzięki współpracy z UŁ wydawane jest interdyscyplinarne, naukowe czasopismo - rocznik „Biuletyn Uniejowski”.

W ramach poprawy wizerunku miasta władze zainwestowały również w rewitalizację jego rynku, w tym odnowiły chodniki, ulice, doświetliły miasto, odnowiły zabytkową, neogotycką wieżę zegarową oraz zrewitalizowały jego nieoficjalny symbol, dominantę i znak charakterystyczny, czyli zamek arcybiskupów gnieźnieńskich pochodzący z XIV wieku wraz z znajdującym się na jego obszarze parkiem. 


\section{c) pozyskiwanie środków unijnych}

Trzecim ważnym wymiarem prowadzonej w mieście polityki jest efektywne pozyskiwanie przez miasto środków zewnętrznych, w tym przede wszystkim pochodzących z UE, choć nie tylko, bo pewien udział mają także środki pochodzące z programów regionalnych i krajowych, m.in. z Wojewódzkiego Funduszu Ochrony Środowiska i Gospodarki Wodnej w Łodzi.

Największe znaczenie mają jednak fundusze pochodzące z UE, a o ich znaczeniu w polityce władz świadczy fakt, że Uniejów już od 2004 roku znajduje się w czołówce miast w Polsce o największej efektywności ich pozyskania i wydatkowania oraz największym dofinansowaniu projektów (tab. 1). Od 2004 roku pozyskał on blisko $190 \mathrm{mln}$ zł na projekty, a wartość dofinansowania w przypadku niektórych z nich wyniosła nawet ponad 90\%.

Tabela 1

Pozycja Uniejowa w rankingu Pisma Samorządu Terytorialnego „Wspólnota” według kryterium udziału wydatków majątkowych finansowane ze środków unijnych w wydatkach majątkowych ogółem w latach 2009-2012

\begin{tabular}{|l|c|c|c|}
\hline \multirow{2}{*}{ Miejscowość } & \begin{tabular}{c}
$|c|$ \\
Pozycja w rankingu \\
\cline { 2 - 3 }
\end{tabular} & $\begin{array}{c}\text { Pisma Samorządu Terytorialnego } \\
\text { „Wspólnota” za lata: }\end{array}$ & $\begin{array}{c}\text { Wydatki majątkowe } \\
\text { finansowane ze środków } \\
\text { unijnych jako \% wydatków } \\
\text { majątkowych ogółem } \\
\text { w latach 2009-2012 (\%) }\end{array}$ \\
\hline Uniejów & 9 & $2009-2012$ & 69,9 \\
\hline Hel & 422 & 1 & 66,5 \\
\hline Szczyrk & 38 & 2 & 65,4 \\
\hline
\end{tabular}

Źródło: opracowanie własne na podstawie: http://www.wspolnota.org.pl/rankingi/.

Potwierdzeniem sukcesów i efektywności działań promocyjnych realizowanych w gminie Uniejów jest przyznawanie miastu, gminie, burmistrzowi i ,Termom Uniejów" wielu nagród na forum regionalnym i ogólnopolskim. Wyróżnienia te świadczą o prawidłowo i atrakcyjnie prowadzonych działaniach w zakresie marketingu terytorialnego Uniejowa. Jednymi z najważniejszych wyróżnień są nagrody w konkursie Ministerstwa Rozwoju Regionalnego „Polska Pięknieje - 7 cudów Funduszy Europejskich" (2009, 2013), w Rankingach Samorządów „Rzeczpospolitej” (2006, 2007, 2009, 2010, 2011, 2012), w Plebiscycie Magazynu National Geographic Traveler „7 Nowych Cudów Polski 2012”, w konkursach Polskiej Organizacji Turystycznej za „Najlepszy Produkt Turystyczny Roku” (Wyróżnienie POT 2011 i Certyfikat POT 2012) (Kaczmarek, Smętkiewicz 2013).

Działania związane z rozwojem infrastruktury i funkcji turystycznych Uniejowa w oparciu o potencjał geotermalny spotykają się z dużym zainteresowaniem 
różnych instytucji naukowych, organizacji, władz, mediów. Jest to potwierdzenie, że Uniejów stanowi także dobry przykład dla innych samorządów lokalnych w Polsce oraz motywację do odważnego ubiegania się o środki unijne.

\section{d) dzialania prospoleczne}

Władze gminy Uniejów stawiają sobie za jeden ze swoich priorytetowych celów działania o charakterze prospołecznym mające za zadanie dbanie o dobro mieszkańców i stałą poprawę jakości ich życia. Przykładami takich działań są m.in.:

- karty rabatowe 50\% na wejścia do kompleksu termalno-basenowego „Termy Uniejów" dla mieszkańców gminy, którzy złożyli deklaracje śmieciowe i uiszczają opłaty za wywóz odpadów,

- bezpłatne wejścia do kompleksu termalno-basenowego „Termy Uniejów” dla członków lokalnych stowarzyszeń kulturalnych i klubów sportowych,

- organizowanie zajęć sportowych w kompleksie termalno-basenowym „Termy Uniejów" dla uczniów szkół gminy Uniejów,

- SMS-owy system bezpośredniego informowania mieszkańców gminy Uniejów o wydarzeniach i różnych sprawach ich dotyczących,

- udział obiektów turystycznych w Uniejowie w akcji „Karta Dużej Rodziny” oraz wsparcie akcji „koperta życia”,

- wspieranie działań aktywizujących osoby starsze, np. Uniwersytet Trzeciego Wieku w Uniejowie, organizowany przez Towarzystwo Przyjaciół Uniejowa,

- przyznawanie jednorazowego stypendium Burmistrza Miasta Uniejów za wyniki w nauce dla uczniów szkół ponadgimnazjalnych i studentów z terenu Gminy Uniejów za osiągnięcia w dziedzinie twórczości artystycznej, upowszechniania i ochrony kultury.

\section{Odbiór społeczny prowadzonej w gminie polityki lokalnej}

Interesującym zagadnieniem w kontekście realizowania przez władze Uniejowa polityki lokalnej jest kwestia jej odbioru społecznego przez mieszkańców gminy i osoby ją odwiedzające. Z badań przeprowadzonych przez K. Smętkiewicz w latach 2010-2013 na potrzeby realizacji rozprawy doktorskiej wynika, że postrzeganie przez mieszkańców i odwiedzających działań podejmowanych przez władze samorządowe gminy Uniejów jest w dużej mierze pozytywne (Smętkiewicz 2013).

Większość osób ankietowanych spośród mieszkańców gminy $(77,5 \%)$ oraz osób odwiedzających $(73,8 \%)$ zgodziła się ze stwierdzeniem, że dzięki wykorzystaniu wód geotermalnych do celów balneoterapeutycznych Uniejów staje się ważnym ośrodkiem lecznictwa uzdrowiskowego w Polsce, a także że Uniejów powinien iść dalej właśnie $\mathrm{w}$ kierunku turystyczno-rekreacyjnym związanym z geotermią - odpowiednio: $92,5 \%$ i $89,2 \%$. Respondenci potwierdzają tym 
samym swoje poparcie dla kierunków działań podejmowanych przez władze gminy. Są oni w zdecydowanej większości także świadomi, że geotermia odegrała i nadal odgrywa kluczową rolę w korzystnych przemianach społeczno-gospodarczych miasta i że to dzięki niej Uniejów ma szansę rozwijać swoje funkcje turystyczno-rekreacyjne. Jako zobrazowanie tych opinii można przytoczyć jedną z wypowiedzi - pamiątkowych wpisów zawartych w Kronice Uzdrowiska Uniejów w 2012 roku: „Świetnie, że w centrum Polski, po odkryciu wód o takim składzie, miasto otrzymało miano uzdrowiska. Wody, atmosfera parku i pałacu mają ogromny wpływ na naszą poprawę zdrowia, nie tylko fizycznego, ale i nastrojów - wypoczynek w pięknej formie. Dziękujemy Włodarzom Miasta, że wytrwale realizują plany i rozwijają możliwości tego pięknego, z wielkimi tradycjami, miejsca (...)".

Większość respondentów zamieszkałych na terenie gminy Uniejów uważa miasto za przykład miejscowości, która właśnie wykorzystaniu wód geotermalnych zawdzięcza swój dynamiczny rozwój społeczno-gospodarczy $(97,4 \%)$ oraz zdecydowaną poprawę atrakcyjności turystycznej (98,7\%). Według prawie wszystkich osób uczestniczących w badaniach (98,7\%), inwestycje geotermalne w Uniejowie były możliwe dzięki skutecznemu pozyskiwaniu funduszy unijnych oraz ich racjonalnemu i pożytecznemu wykorzystaniu. Odpowiedzi takie wskazują na kluczową rolę działań podejmowanych przez władze samorządowe i ich pozytywnych efektów.

O obraniu przez władze gminy Uniejów właściwego kierunku rozwoju gminy, takiego który jest akceptowany przez jej mieszkańców, świadczy również fakt, że około $75 \%$ badanych przedstawicieli społeczności lokalnej wskazywało na pozytywne skutki wynikające z posiadania przez Uniejów statusu uzdrowiska. Najczęściej wskazywanymi korzyściami są: wzrost atrakcyjności turystycznej miasta i regionu ( $26,7 \%$ odpowiedzi), poprawa sytuacji na lokalnym rynku pracy (23,7\% odpowiedzi), rozwój gospodarczy miasta (13,8\% odpowiedzi), większa promocja i prestiż miasta (10,8\% odpowiedzi), a także korzyści finansowe dla gminy, poprawa stanu środowiska przyrodniczego, poprawa oferty usług leczniczych oraz jakości życia społeczności lokalnej i wyglądu miasta. Dowodem na to, że mieszkańcy gminy zauważają pozytywne przemiany zachodzące w Uniejowie w kierunku pełnienia funkcji ośrodka turystycznego, są przykładowe wypowiedzi respondentów: „Uniejów z ospałego miasteczka stał się szybko rozwijającym się centrum rekreacyjnym i turystycznym, głównie z powodu budowy basenów wykorzystujących ciepło wód termalnych oraz licznych imprez, w tym konferencji i spotkań naukowych. Sprzyja temu również dobre zaplecze gastronomiczne i atrakcyjność turystyczna miejscowości (...)”, „Sądząc po kolejnych inwestycjach realizowanych w Uniejowie istnieje duża szansa utworzenia w centralnej Polsce atrakcyjnego centrum uzdrowiskowo-turystycznego, promieniującego przykładem na inne miejscowości mające złoża geotermalne, jeszcze niewyko- 
rzystywane (...)”, „Wzrost liczby turystów powoduje rozwój gminy, zachodzą pozytywne zmiany, są duże nakłady, ale za to też duże korzyści”, „Rozwój miasteczka powoduje, że pięknieje, jest ono bardziej zadbane i bardziej atrakcyjne dla turystów". Przytoczone opinie i nastawienie społeczności lokalnej świadczy o akceptacji działań decydentów oraz o tym, że opinie i interesy tych grup są ze sobą zbieżne. Wyniki przeprowadzonych badań wskazują na to, że mieszkańcy gminy i osoby odwiedzające $\mathrm{w}$ znacznym stopniu identyfikują się z działaniami podejmowanymi przez władze i popierają je.

\section{Wnioski}

1. Polityka lokalna spełnia szereg ważnych funkcji, z których najważniejszą jest zapewnienie rozwoju lokalnego danej jednostki terytorialnej. Stąd w literaturze często podkreśla się, że istotą, nadrzędnym celem polityki lokalnej powinno być jej nastawienie przede wszystkim na własne środowisko i jego interesy. Przykład Uniejowa dowodzi, że są samorządy, które działają zgodnie z tą dewizą i odnoszą sukces.

2. Próbując zdefiniować sposób prowadzonej w Uniejowie polityki lokalnej należy zauważyć, że obecnie samorząd ten nie funkcjonuje w sposób tradycyjny, lecz wpisuje się w obowiązujący coraz częściej na Zachodzie trend określany mianem Nowej Kultury Politycznej. Oczywiście nie wszystkie wyróżnione w ramach tej koncepcji idee znalazły w Uniejowie zastosowanie praktyczne, niemniej jednak ich wpływ szczególnie na sposób zarządzania tą gminą jest bardzo wyraźny. W wymiarze gospodarczym ma ona swoje odzwierciedlenie po pierwsze, we wzroście zainteresowania samorządowców wspieraniem przede wszystkim rozwoju gospodarczego, a nie tylko wykonywaniem usług, a nawet więcej, sprawy gospodarki znalazły się tu ewidentnie w centrum realizowanej strategii, a po drugie w odejściu od tzw. instrumentów bezpośrednich (kosztowych) do pośrednich budowanych na zasadzie partnerstwa między aktorami publicznymi i prywatnymi. W Uniejowie samorządowcy wyraźnie bowiem postawili na podaż dóbr publicznych ( $\mathrm{tj}$. czyste powietrze, warunki środowiska przyrodniczego, środowisko kulturowe, czy jakość życia) kosztem uwagi zwracanej tradycyjnie na dobra prywatne, tj. ulgi podatkowe przyznawane pojedynczym przedsiębiorstwom. W wymiarze politycznym realizacja tej koncepcji przejawia się natomiast odejściem od rozumienia władzy jako opartej na zależnościach hierarchicznych i zdolnej jedynie do wydawania i egzekwowania poleceń na rzecz zdolności do osiągania wyznaczonych celów. W wymiarze związanym ze stylem zarządzania - sprowadza się to po pierwsze do przejęcia i zastosowania niemal wprost metod charakterystycznych dla sektora prywatnego, takich jak: planowanie strategiczne, niektóre techniki planowania finansowego czy zarządzanie przez cele, a po drugie do oddzielenia odpowiedzialności za usługi od ich bezpośredniego wykonania. 
3. Czas pokaże, czy obrany ponad 10 lat temu przez włodarzy gminy kierunek jej rozwoju był słuszny. Już teraz jednak istnieje wiele obiektywnych dowodów na to, że tak jest, o czym świadczy chociażby dynamiczny, wymierny rozwój społeczno-gospodarczy i diametralna przemiana oblicza gminy Uniejów, a szczególnie samego Uniejowa. Sądzimy, że sposób prowadzenia tam polityki lokalnej powinien stanowić przyczynek (punkt odniesienia) do dodatkowych refleksji w wewnątrzkrajowych debatach na temat samorządności i rozwoju lokalnego, tym bardziej, że w Polsce, jak na razie większość samorządów wciąż funkcjonuje w sposób tradycyjny.

\section{LITERATURA}

Gorczyczewska E., Smętkiewicz K., 2013, Budowa i promocja marki miejsca na przykładzie uzdrowiska termalnego Uniejów, [w:] Heffner K., Twardzik M. (red.), Nowoczesne instrumenty polityki rozwoju lokalnego - zastosowanie i efekty w matych miastach, Uniwersytet Ekonomiczny w Katowicach, Katowice.

Kaczmarek J., Smętkiewicz K., 2013, Potencjał wykorzystania wód geotermalnych na przykładzie Uzdrowiska Uniejów, „Cieplne Maszyny Przepływowe Turbomachinery”, 143, Wydawnictwo Instytutu Maszyn Przepływowych Politechniki Łódzkiej, Łódź.

Kulawiak A., 2013, Wpływ władz lokalnych na rozwój gospodarczy miasta. Przykład Uniejowa, [w:] Ciok S., Raczyk A. (red.), Wyzwania polityki regionalnej i lokalnej, Rozprawy Naukowe Instytutu Geografii i Rozwoju Regionalnego Uniwersytetu Wrocławskiego, 27, Wrocław.

Markowski T., 1999, Zarzadzanie rozwojem miast, PWN, Warszawa.

Masik G., 2010, Typy polityki lokalnej. Przykład strefy suburbanizacji aglomeracji trójmiasta, ,Studia Regionalne i Lokalne”, 1(39), Centrum Europejskich Studiów Regionalnych i Lokalnych UW (EUROREG), Warszawa.

Needhan B., 1982, Choosing the Right Policy Instruments, Gower Hants.

Parysek J., 2001, Podstawy gospodarki lokalnej, Wydawnictwo Uniwersytetu Adama Mickiewicza, Poznań.

Regulski J., 1986, Planowanie miast, PWE, Warszawa.

Regulski J., Kocon W., Ptaszyńska-Wołoczkowicz M., 1988, Władze lokalne a rozwój gospodarczy, PWE, Warszawa.

Smętkiewicz K., 2013, Świadomość spoteczna wykorzystania wód geotermalnych w województwie łódzkim i landzie Styria, maszynopis rozprawy doktorskiej, Wydział Nauk Geograficznych UŁ.

Smętkiewicz K., 2014, Świadomość spoteczna wykorzystania wód geotermalnych w województwie tódzkim i landzie Styria w kontekście zrównoważonego rozwoju regionów, Wydawnictwo Ibidem, Łódź.

Strategia Rozwoju Gminy Uniejów na lata 2013-2020.

Studia i materiały, Księży Młyn Dom Wydawniczy, Łódź.

Suliborski A, Walkiewicz D., 2009, Wspótczesne zróżnicowanie społeczno-gospodarcze województwa łódzkiego, [w:] Badziak K., Łapa M., (red.), Województwo łódzkie 19192009. 
Swianiewicz P., 2004, Nierówne koalicje - liderzy miejscy w poszukiwaniu nowego modelu zarzadzania rozwojem, EUROREG, Warszawa.

„Uniejowskie Strony”, 2014, nr 4/44.

Winiarski B., 1986, Instrumenty polityki przestrzennej. Aspekt praktyczny, „Biuletyn KPZK PAN", Warszawa.

\title{
Źródła internetowe
}

http://www.wspolnota.org.pl/rankingi (dostęp: 18.03.2015).

http://wybory2002.pkw.gov.pl/wojt/t1/gw1/w10/p1011/g101104.html (dostęp: 13.04.2015).

http://wybory2006.pkw.gov.pl/kbw/geoGminafea5.html?id=101104\& (dostęp: 13.04.2015). http://wybory2010.pkw.gov.pl/geo/pl/100000/101104.html\#tabs-6 (dostęp: 13.04.2015).

\section{POLITICS LOCAL MUNICIPALITY UNIEJÓW - SOME ASPECTS OF THEORY AND PRACTICE}

\begin{abstract}
The article discusses the way (method) carried out by the local authorities in local politics in a small town on the example of Uniejów. The characteristics of this problem is based on the scheme presented by J. Regulski creation in local politics. Thus, the author focused primarily on the identification of vision and goals pursued in Uniejow local politics, the presentation adopted by the local authority strategies, including the stages of its formation and the tools used and the analysis of the action taken in assuming pursue the adopted vision of development. In addition, the article discusses the social studies whose objective was to identify and assess the degree of satisfaction of residents and tourists from visiting him pursued by the authorities of local politics.
\end{abstract}

Key words Local politics, local authorities, local development, Uniejów.

Dr Anita Kulawiak

Katedra Geografii Regionalnej i Społecznej Wydział Nauk Geograficznych, Uniwersytet Łódzki

Dr Karolina Smętkiewicz

Dział Promocji Urzędu Miasta w Uniejowie 